\title{
Evaluasi Pelatihan Menilai Berita Palsu atau "Hoax" Pada Kelompok Arisan Dosen Perempuan
}

\author{
HADIYATI $^{1}$, BAMBANG SUROTO $^{1}$, FATKHURAHMAN ${ }^{1}$ \\ ${ }^{1,2,3}$ Universitas Lancang Kuning \\ Jln. Yos Sudarso KM 08 Rumbai Telp. (0761) 52581 \\ E-mail : fatkhurrahman@unilak.ac.id
}

\begin{abstract}
The situation of partners regarding the ability to judge fake news is still low, where there is a desire from partners to listen about how to assess the correct news and what aspects they need to see. Then as female lecturers and their intellectual circles their attitude has an impact on actions in the form of re-delivering news to students and if the news is not true it will result in misleading information submitted. Through the training method of assessing fake news or hoaxes to female lecturers who are members of the arisan group, namely by providing knowledge, understanding and skills in assessing news stories. Through lectures and practices and assessments carried out using pre test and test post will give female lecturers a more tangible assessment of the success of this training. After the training was held, judging the hoaxes or hoaxes of female lecturers could earnestly take part in the training, it was seen from the $50 \%$ targeted participants present and up to the end of the training activities reached $70 \%$ and then after pre test and post test for the participants produced ablity assesses fake news, understands the intent of disseminating fake news and is also able to assess and behave after receiving false news so as to produce correct information and distinguish what is right and what is wrong and finally will return it to students in class.
\end{abstract}

Keywords: Assessing Fake News Training, Hoaxes

Berita bohong atau Hoax merupakan fenomena berkembangan di media sosial yang sedang sering dibicarakan dan dipermasalahkan. Beberapa kasus tentang penyebaran berita bohong di media sosial sampai pada ranah penuntutan di pengadilan. Tanpa disadari seolah-olah hanya sebuah permainan saja, dan dengan mudah mendapatkan berita bohong dan terkesan menarik di media sosial dan yang lebih menjadi persoalan pada saat berita hohong tersebut disebarkan atau di share ke publik. Kendala utama dalam menyikapi kondisi tersebut yaitu masih rendahnya pengetahuan serta pemahaman dan bahkan kemampuan menilai sehingga sikap menanggapi berita bohong tersebut menimbulkan masalah.

Kaum hawa atau perempuan menjadi kaum yang sangat sosial, dimana untuk kondisi saat ini mereka adalah kaum yang sangat aktif menggunakan media sosial untuk berbagai keperluannya. Bahkan kaum perempuan sudah menjadi salah satu sumber penyebar berita yang paling efektif. Kaum perempuan suka berteman dan berkelompok untuk membicarakan berbagai persoalan yang mereka hadapi dan bahkan mencari solusi dari permasalahan tersebut. Mereka sering curhat dan saling berempati.

Dosen sebagai salah satu pendidik yang aktif dalam menyebarluaskan pengetahuan dan informasi. Melalui perkuliahan di dalam kelas dan bahkan diskusi dalam seminar serta pada banyak kesempatan dosen menjadi sangat aktif untuk berbagi pengetahuan dan informasi. Dosen perempuan salah satunya menjadi kelompok yang paling memberikan pengaruh besar dalam penyebaran sebuah informasi, pengetahuan dan juga berita. Karena sifat alamiahnya tersebut, mereka akan dengan sangat aktif memanfaatkan media sosial sebagai sarana untuk menyalurkan kebiasaan yang baginya memberikan manfaat. Namun apabila informasi yang disebarkan merupakan 
informasi yang tidak benar alias bohong alias hoax, maka dosen ini akan menjadi bulan-bulanan.

Penyebaran hoax di media sosial Indonesia memasuki fase yang cukup mengkhawatirkan, karena berdampak serius terhadap kehidupan sosial warga bangsa. Pertemanan putus, keluarga tidak harmonis, bahkan konflik horizontal sempat terjadi ketika ada sebagian warga yang termakan oleh berita hoax. Nugroho, S. E. (2017).

Kemampuan menilai kebenaran sebuah berita dalam media sosial merupakan permasalahan yang ditemukan untuk menghindari penyebaran pengetahuan dan informasi yang tidak tepat. Hambatannya adalah kesulitan menilai indikator kebenaran sebuah berita pada media sosial dan juga mudahnya fitur penyebaran berita yang tersedia dengan hanya melakukan klik saja maka berita sudah disampai ke public.

Salah satu kelompok dosen perempuan yang menjadi mitra dalam kegiatan ini adalah kelompok arisan dosen perempuan di Sekolah Tinggi Ilmu Ekonomi Riau. Kelompok ini memiliki kegiatan rutin berkumpul setiap bulan dan dengan agenda untuk bisa membicarakan berbagai peramasalahan seputar perkuliahan dan juga masalah sosial lainnya. Pada saat mereka berkumpul untuk acara arisan, mereka selalu menyelingi kegiatannya dengan berbagi informasi dan berbagi pengalaman baru. Selalunya mereka akan membahas mengenai hal-hal yang viral alias sedang berkembang pesat saat ini. Kondisi ini terkadang mendapatkan perdebatan, karena masih dinilai samar-samar beritanya dan bahkan mereka tidak jarang merasa ragu terhadap kebenaran sebuah berita yang mereka diskusikan.

Pada dasarnya mereka sudah mengetahui kabar berita yang berkembang dan bahkan selalu mereka mempersoalkannya, namun keterbatasan pemahaman yang mereka dapatkan dan ditambah dengan sudah menjadi kebiasaan kaum hawa senang akan sebuah berita apatah lagi berita yang hot alias sedang dalam perbincangan diseantero, menyebabkan mereka terbelit dalam sebuah jeratan ketidakbenaran dan hal ini akan berdampak lebih buruk lagi apabila dosen perempuan menyampaikan ketidakbenaran tersebut kepada mahasiswa.

Akibat yang dirasakan apabila dosen perempuan menyampaikan ketidakbenaran kepada mahasiswa adalah sebuah tindakan sesat dan menyesatkan dan ini akan dapat dihindarkan apabila dosen perempuan mendapatkan penjelasan dan pemahaman yang baik dalam menilai sebuah berita. Apakah berita yang diperolehnya benar atau salah akan dengan lebih bermanfaat lagi, tidak hanya pada dirinya sendiri juga bagi mahasiswa.

Oleh karenanya, dinilai perlu diberikan pelatihan kepada dosen perempuan yang tergabung dalam kelompok arisan dosen, mengenai pelatihan menilai berita palsu atau hoax. Hoax adalah istilah untuk menggambarkan suatu berita bohong, fitnah, atau sejenisnya. Hoax sendiri telah menimbulkan keresahan dalam masyrakat bahkan dapat memecah belah persatuan dan salah satu solusi untuk mengatasi hoax tersebut adalah membangun daya pikir masyarat agar tidak mudah terprovokasi oleh hoax yang tidak bisa dipastikan kebenarannya, mengajak masayrakat agar cerdas dalam melakukan literasi informasi, mengecek kebenaran informasi, sebelum melakukan share atau berbagi informasi melalui media sosial, disisi lain pemerintah harus tanggap terhadap hoax yang beredar yang meresahkan masyarat, meskipun saat ini pemerintah telah membentuk satgas antihoax, pemerintah diharapkan terus melakukan verifikasi atau akreditasi terhadap media mainstream maupun para penyedia berita melalui televisi, koran dan media online, termasuk melakukan akreditasi dan indenpedensi terhadap para wartawan yang menyajika informasi serta menutup situs-situs yang menyebarkan 
berita hoax dan terus giat mensosialisasikan dan menerapkan UU ITE. (Pakpahan, R. 2017)

Berita hoax indikatornya adalah penyimpangan informasi, dramatisasi fakta, serangan privasi, pembunuhan karakter, meracuni pikiran anak, penyalahgunaan media sosial menerima dan menyebarkan berita hoax, kepercayaan dan respon pengguna media sosial terhadap berita hoax, dengan penafsiran pengaruh berita hoax terhadap perilaku pengguna (user) media sosial. Sormin, D. (2017)

Penyebaran berita hoax ditujukan untuk memengaruhi orang sekalipun informasi yang diberikan tidak benar menciptakan stigma seolah-olah beritanya benar. Interaksi sama sekali tidak terpengaruh dengan adanya berita hoax, namun merasa terganggu, sebab dikwatirkan akan mempengaruhi keputusan dalam memilih. Mansyah, B. (2017)

Riyanto, B., \& Hastuti, N. H. (2017) bahwa mahasiswa merupakan kaum intelektual calon pemimpin masa depan, dengan demikian bagaimana sikap mahasiswa terhadap berbagai persoalan bangsa perlu dicermati. Penelitian tentang bagaimana sikapnya terhadap hoax yang viral di media sosial penting untuk dilakukan, apalagi dikalangan para aktivis mahasiswa yang cenderung kritis jika dibandingkan dengan mahasiswa nonaktivis. Sebagai kaum terdidik, mahasiswa seharusnya mampu memahami, menganalisis, menilai, dan mengkritisi informasi yang dibawa oleh teknologi komunikasi. Sayangnya malah banyak mahasiswa yang ikut terhegemoni. Selain menyebarkan informasi hoax, tidak melek terhadap informasi di dalam gadget.

Menurut AJI dalam Pakpahan (2017) yang mengatakan kemampuan menilai sebuah berita dapat dilihat dari: penilaian judul, penilaian situs, kontens, fhoto dan sumber berita. Berdasarkan uraian di atas, maka dapat dijelaskan bahwa masalah yang dihadapi dosen perempuan dalam menilai berita palsu masih rendah, sehingga melalui pelatihan menilai berita palsu ini akan dapat meningkatkan pengetahuan, pemahaman dan ketrampilan dosen perempuan dalam menilai kebenaran sebuah berita.

Melihat kondisi tersebut, potensi permasalahan yang akan dihadapi dosen perempuan akibat dari ketidakmampuan menilai berita bohong dan menyebarluaskannya di media sosial cukup besar. Oleh karena itu perlu adanya pelatihan yang diberikan dalam rangka mengenal berita bohong atau hoax dan bagaimana cara bersikap setelah mendapatkan sebuah berita bohong tadi.

\section{METODE}

Dalam rangka pelaksanaan pengabdian pada masyarakat maka lokasi pengabdian kepada masyarakat yakni di Sekolah Tinggi Ilmu Ekonomi Riau Panam Pekanbaru. Pengabdian ini ditujukan kepada dosen perempuan yang tergabung dalam kelompok arisan. Dosen perempuan yang berasal dari Sekolah Tinggi Ilmu Ekonomi Riau.

Untuk melaksanakan kegiatan tersebut digunakan beberapa metode pelatihan yaitu:

1. Metode ceramah: hal ini dipilih untuk memberikan penjelasan tentang penilaian berita palsu meliputi: penilaian judul, penilaian situs, kontens, fhoto dan sumber berita.

2. Tanya jawab: metode ini digunakan untuk meningkatkan pemahaman dalam menilai keanehan judul berita, legalitas situs, validasi kontens, keaslian fhoto dan kejelasan sumber berita.

3. Praktek: yakni dengan mempraktekkan secara langsung bagaimana membedakan dengan contoh berita benar dan berita palsu.

\section{HASIL}

Berdasarkan hasil pengabdian yang dilaksanakan pada tanggal 11 April 2018 lalu pada kelompok arisan dosen perempuan tentang "Pelatihan menilai 
berita bohong atau hoax", maka mengukur tingkat keberhasilan kegiatan yang telah dilaksanakan dengan cara melakukan evaluasi 2 (dua) tahapan yaitu sebelum (pretes) dan sesudah (pos tes).

Kegiatan evaluasi ini bertujuan untuk melihat seberapa jauh pengetahuan peserta pengabdian kepada masyarakat ini memahami tentang materi pelatihan yang diberikan. Indikator tingkat keberhasilan kehadiran peserta setelah disebarkan undangan dari 17 orang, yang hadir mencapai 13 orang dan hal ini mencapai $76 \%$. Kondisi ini dinilai berhasil karena target yang ditetapkan adalah hadir melampaui jumlah yang seharusnya.

Pelaksanaan pelatihan ini menjadi salah satu upaya untuk menambah pengetahuan bagi dosen perempuan guna menyikapi penyebaran berita bohong pada media sosial. Hasil evaluasi dari pelaksanaan melalui pre tes dan post tes dari peserta dapat dibagi pada empat pertanyaan utama antara lain: mengenai pengetahuan dosen terhadap berita bohong yang berkembang. Kemudian juga mengenai pemahaman mereka terhadap maksud dan tujuan disebarkannya berita bohong dan bagaimana menilai berita bohong tersebut serta bagaimana sebaiknya bersikap setelah mengetahui sebuah berita itu bohong, berikut ini ulasannya.

\section{Tingkat Pengetahuan Peserta terhadap Berita Bohong}

Berdasarkan diskusi dan jawaban dengan peserta pada dasarnya peserta belum mengetahui dengan baik mengenai sebuah berita pada media sosial apakah benar atau bohong dan kondisi ini dapat dilihat pada gambar berikut:

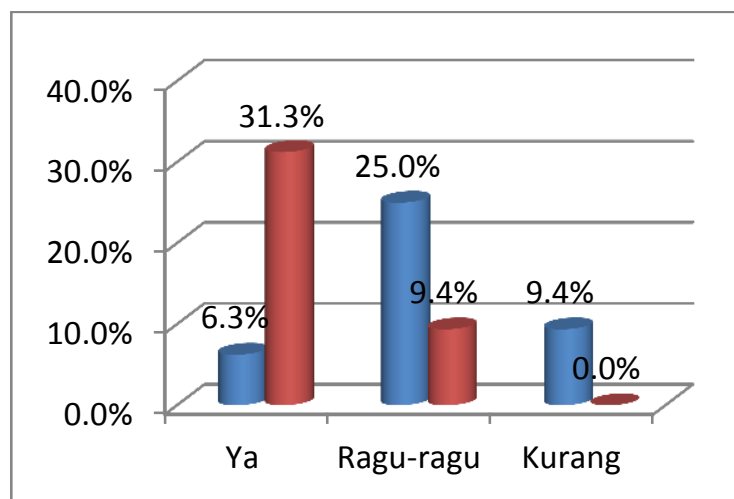

Gambar 1: Pengetahuan Peserta Terhadap Keberadaan Berita Bohong

Dari gambar tersebut dapat dijelaskan bahwa pada dasarnya dosen perempuan ragu akan kebenaran sebuah berita dan bahkan yang mengetahui dengan baik hanya sedikit sekali. Kemudian setelah diberikannya pelatihan akan keberadaan sebuah berita tersebut, maka mereka baru mengalami peningkatan pengetahuan dan bahkan sebagian dari mereka merasa malu, karena sudah selalu membaca berita bohong tanpa mengkaji terlebih dahulu kebenarannya dan juga langsung menyampaikannya kepada mahasiswa di kelas. Hal ini dirasakan oleh dosen perempuan yang ikut program pelatihan dan mereka lebih hati-hati ke depannya dalam rangka mengkonsumsi berita bohong.

\section{Tingkat Pemahaman Peserta mengenai Manfaat Berita Bohong disebarkan di Media Sosial}

Sebuah berita yang dibuat dan pada dasarnya disebarkan pada kelompokkelompok kecil dengan tidak memiliki sumber yang jelas dan sampai kepada kelompok-kelompok media sosial dan langsung mendapatkan perhatian yang sangat luas oleh dunia maya. Hal ini selalu terjadi dan apakah selama ini dosen perempuan yang ikut pelatihan sudah memahami maksud dibuatnya sebuah berita bohong, dapat dilihat pada gambar berikut ini: 


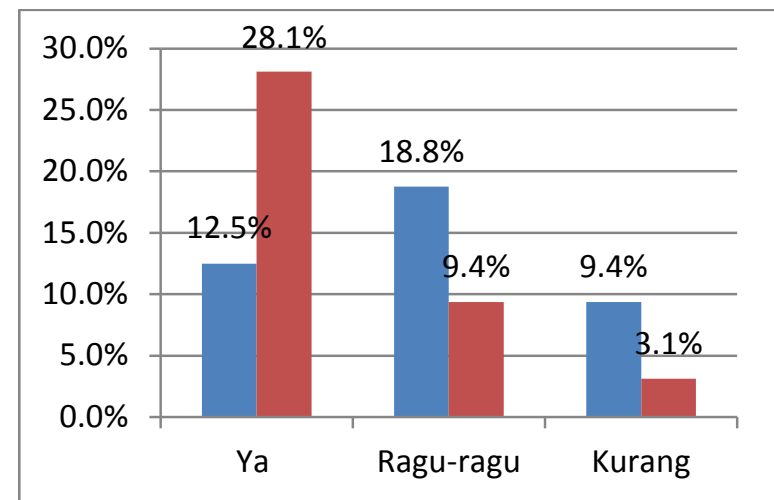

Gambar 2 : Pemahaman terhadap Maksud dibuatnya Berita Bohong

Sebagian besar dari peserta pelatihan sebelum mengiktui pelatihan belum memahami degan baik dan bahkan ragu akan kemampuannya memahami maksud dari dibuatnya berita bohong yang tersebar di media sosial. Namun setelah mereka mendapatkan penjelasan akan maksud yang sesuangguhnya dari pembuat berita seperti maksud ingin terkenal dan maksud ingin mempengaruhi kelompok-kelompok tertentu untuk memusuhi kelompok lain atau adu domba dan bahkan maksud lainnya. Peserta setelah mendengarkan penjelasannya lebih memahami dibuatnya berita bohong yang tersebar pada media sosial.

\section{Tingkat Kemampuan Menilai Indikator Berita Bohong}

Sebuah berita apakah benar atau bohong pada dasarnya dapat dilihat dengan baik dalam berbagai kondisi, seperti yang digunakan dalam penjelasan kepada peserta pelatihan antara lain berkenaan dengan judul berita, biasanya berita yang judulnya heboh selalu perlu diwaspadai, kemudian sumber berita tidak jelas, lembaga penerbit tidak jelas dan kemudian berita yang sudah pernah dipublikasikan sebelumnya. Kondisi bagaimana kemampuan peserta sebelum dan setelah mendapatkan pelatihan dapat dilihat pada gambar berikut ini:

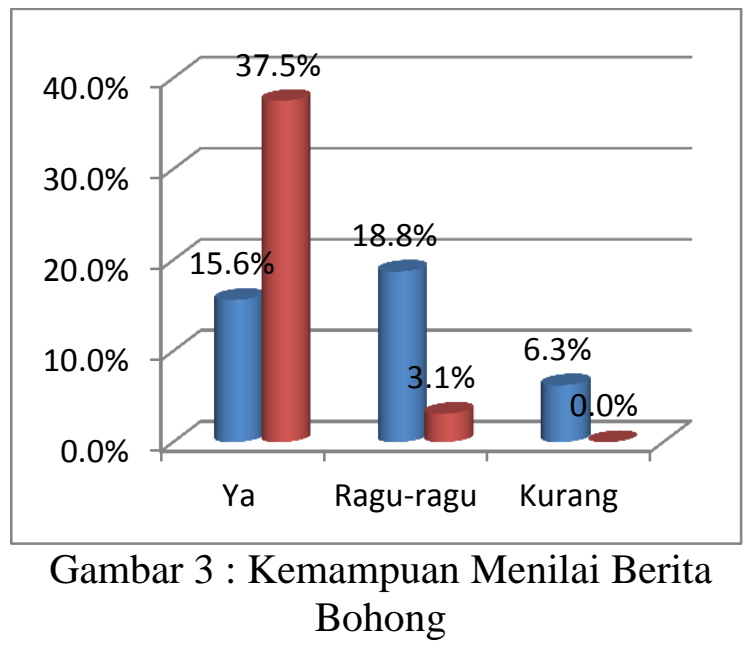

Dari data tersebut dapat dijelaskan bahwa setelah mengikuti pelatihan kemampuan menilai kebenaran sebuah berita sudah tumbuh yang semula kemampuannya hanya mencapai $15,6 \%$ meningkat menjadi $37,5 \%$ walaupun masih sebagian dari mereka masih ragu dalam menggunakan penilaian, hal ini disebabkan keterbatasan waktu yang digunakan dalam pelatihan.

\section{Tingkat Sikap Menshare Saat Mendapatkan Berita Bohong}

Sikap peserta dalam mendapatkan sebuah berita pada media sosial, misalnya pada saat sebuah berita dinilai penting untuk diinformsikan kepada orang terdekat dan bahkan kerabat akan menjadi lebih cepat disampaikan dan bahkan pada saat dibaca judulnya saja mereka sudah langsung menshare ke koleganya. Namun setelah mereka baca berita yang sebenarnya terjadi baru mereka menyadari bahwa yang mereka share adalah berita yang tidak benar alias hoax.

Setelah mendapatkan pelatihan adanya sebuah komitmen yang dibangun peserta untuk selalu berhati-hati menshare sebuah berita. Hal ini disadari bahwa sikapnya akan berdampak fatal. Bagaimana jawaban peserta terhadap kondis tersebut dapat dilihat pada gambar berikut ini: 


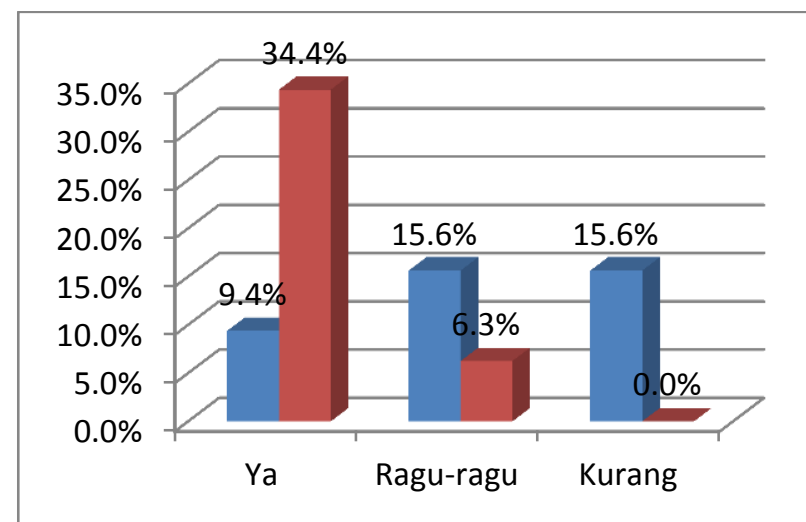

Gambar 4 : Sikap Peserta Pasca Pelatihan

Dari data tersebut dapat dijelaskan bahwa setelah mengikuti pelatihan sikap peserta dalam menyebarluaskan terhadap sebuah berita semakin berhati-hati, semual hanya 9,4\% yang berhati-hati, setelah mendapatkan pelatihan mencapa $34,4 \%$ yang berusaha untuk berhati-hati. Namun masih ada yang ragu-ragu terhadap sikap mereka, karena hal ini juga berdampak kepada update informasi dan ketinggalan berita yang dirasakan. Memang sebagian dari peserta mengatakan, konsumsi berita yang unik dan menarik terkadang menjadi bahan pembicaraan setiap anggota kelompok.

\section{PEMBAHASAN}

Berdasarkan uraian tersebut, maka dapat lebih jelas dilihat adanya perubahan yang cukup signifikan setelah diberikannya pelatihan menilai berita bohong dalam media sosial. Yang paling mendapatkan perhatian adalah sikap menshare berita bohong, bahwa peserta membuat komitmen dalam diri untuk selalu berhati-hati dalam menyebarkan berita bohong sebelum dibaca lebih dalam. Kemudian setelah dibaca perlu dilakukan cek dan ricek dari sumber berita dan penerbit berita.

Peningkatan kemampuan dosen perempuan menjadi bagian penting dalam meningkatkan kinerja lembaga. Hal ini sesuai dengan pendapat Rahman, F., \& Suroto, B. (2018) yang mengatakan kinerja dosen dapat selalu ditingkatkan melalui pelatihan dan pengalaman belajar sendiri.

Jugas ditegaskan oleh Novita, N. (2016) bahwa perempuan selalu berpikir

Diklat Review: Jurnal Manajemen Pendidikan dan Pelatihan kritis dan kreatif dalam menghadapi kondisi ekonomi rumah tangga. Melalui diskusi sesama mereka di kelopoknya akan menghasilkan informasi yang produktif.

\section{SIMPULAN}

Berdasarkan hasil pelaksanaan pengabdian yang dilaksanakan di lapangan berkaitan dengan penilaian berita bohong alias hoax, maka dapat ditarik beberapa kesimpulan antara lain: Peserta pelatihan mengalami perubahan yang cukup signifikan setelah mendapatkan pelatihan dalam rangka mengenal, memahami dan mampu menilai sebuah berita pada media sosial dan informasi ini sangat berguna bagi peserta dan peserta antusias mengikuti pelatihan hingga akhir kegiatan.

Sikap lebih hati-hati dan berkomitmen dalam diri peserta tanpak setelah mendapatkan penjelasaan akan berita bohong. Untuk selalu berhati-hati dalam menerima sebuah berita dan kehatihatian ini lebih membuat kualitas berita yang disebarkan akan semakin baik.

\section{DAFTAR RUJUKAN}

Aribowo, E. K. (2017). Menelusuri Jejak Hoaks Dari Kacamata Bahasa: Bagaimana Mendeteksi Berita Palsu Sedini Mungkin. Retrieved from osf. io/preprints/inarxiv/k2at4.

Bambang, S. (2018). Analisis Kemampuan Mahasiswa Menilai Berita Palsu atau 'hoax". Hasil Penelitian, Unilak, Pekanbaru.

Mansyah, b. (2017). Fenomena berita hoax media sosial (facebook) dalam menghadapi pemilihan umum gubernur dki jakarta tahun 2017 (doctoral dissertation, perpustakaan).

Novita, N. (2016). Analisis Kreatifitas Kelompok Masyarakat Menghadapi Kondisi Ekonomi Vol. 2, No. 2, September 2018 
Rumah Tangga. Jurnal Daya Saing, 2(2), 150-159.

Nugroho, s. E. (2017). Upaya masyarakat anti fitnah indonesia mengembalikan jatidiri bangsa dengan gerakan anti hoax. Prosiding konferensi nasional peneliti muda psikologi indonesia, 2(1), 1-4.

Pakpahan, r. (2017). Analisis fenomena hoax diberbagai media sosial dan cara menanggulangi hoax. Konferensi nasional ilmu sosial \& teknologi, 1(1).

Riyanto, B., \& Hastuti, N. H. (2017). literasi media digital mahasiswa surakarta dalam mensikapi hoax di media sosial. Transformasi, 1(33).

Sormin, d. (2017). Pengaruh berita hoax terhadap perilaku pengguna media sosial ditinjau dari uи no. 11 tahun 2008 tentang informasi dan transakasi elektronik (studi kasus universitas negeri medan fakultas ilmu sosial jurusan ppkn angkatan 2013) (doctoral dissertation, unimed).

RAHMAN, F., \& SUROTO, B. (2018). MODEL PENGEMBANGAN KINERJA DOSEN SWASTA (Studi pada Karyawan yang berprofesi sebagai Dosen). Human Sustainability Procedia. 